\title{
Irrigation Water Management by Using Remote Sensing and GIS Technology to Maintain the Sustainability of Tourism Potential in Bali
}

\author{
Putu Aryastana $^{1, a)}$, Cok Agung Yujana ${ }^{2, b)} \&$ I Made Ardantha ${ }^{2, c)}$ \\ ${ }^{1)}$ International Ph.D. Program in Environmental Science and Technology (University System of \\ Taiwan), National Central University, Taoyuan City, Taiwan (R.O.C.) \\ ${ }^{2)}$ Department of Civil Engineering, Warmadewa University, Denpasar, Indonesia \\ Correspondent : ${ }^{a}$ aryastanaputu@yahoo.com, ${ }^{b}$ cokyujana@gmail.com \& \\ c)madeardantha@gmail.com
}

\begin{abstract}
This paper reviews the literature on the potential use of remote sensing and GIS technology in irrigation water management to support the preservation of the Subak irrigation system in Bali. Subak is a system that has survived for a very long time faces challenges in irrigation water management. Remote sensing technology provides an opportunity to get identification, analysis, and monitoring of land use, irrigation area, irrigation infrastructures, water supply source, water use, crop type, water rights, irrigation scheduling, yield estimates, nursery monitoring, crop disease detection, evaluate fruit maturity, and detection of bruises on fruit. The integration of remote sensing technology and GIS is expected to be able to make irrigation infrastructure assets and water management more effective and efficient.
\end{abstract}

Keyword : infrastructure management, Bali; irrigation; management, remote sensing

\section{INTRODUCTION}

The economy of Bali Province evolves from agriculture, small industry, and the tourism sector (Budiasa \& Ambarawati, 2014). Agriculture and specifically the planting of rice had been the main economic foundation in Bali, before developments in tourism and urban growth (Mitchell, 1994). Bali as one of the world's tourist destinations is very famous for its various tourism potentials, such as the beach, waterfalls, mountainous areas, ritual tourism, cultural tourism, ecotourism, and also agricultural tourism. The number of foreign tourists visiting Bali reached 5.7 million people in 2017, an increase of $15.62 \%$ from the previous year (BPS, 2018).

Agricultural tourism in Bali develops because of the shape of terraced rice fields which is a unique cultural landscape (Yekti, Schultz, Norken, \& Hayde, 2017) and also because of the incorporation of Hindu religious philosophy in the management of rice fields. This philosophy is known as Tri Hita Karana which refers to three sources of prosperity, equality, and balance between humans and gods, humans and other humans, and humans and their environment (Sørdalen, 2011). It is connected with many core ideas related to sustainable development (Mitchell, 1994). The uniqueness of the landscape lies in the management of irrigation water that flows into the rice fields.

The irrigation water management system in Bali is known as the subak irrigation system (Roth, 2011). This system already exists from the ninth century, which has facilities such as irrigation networks and structures, irrigation areas, and regulations (Norken, Suputra, \& Arsana, 2015). The construction and operation system of the subak irrigation scheme is based on mutually agreed principles including technical issues, agricultural management, and religious communities. Subak irrigation water management uses a diversion weir (empelan) which was 
built several points along the river. Through this weir, irrigation water is supplied to the boxes equally (tembuku) and then to the paddy fields of each subak member by using water distribution units (tektek/kecoran) (Norken, Suputra, \& Arsana, 2015; Yekti, Schultz, Norken, \& Hayde, 2017).

The subak system is recognized as belonging to the Balinese indigenous community, both nationally and world cultural heritage (Fowler, 2003), so that subak needs to be protected, preserved, enhanced, and revitalized so that its main functions still exist (Lanya, Subadiyasa, Sardiana, \& Adi, 2015). Subak has several challenges today, including the low desire of the younger generation to work in the agricultural sector, the decreasing area of paddy fields due to land-use change to support tourism accommodation, lack of irrigation water due to conflicts of interest with different users, modernization and technological changes are sufficient high (Yuliana, 2015). Thus the traditional subak irrigation system needs to be modified and transformed to the limited availability of water, by applying an integrated with remote sensing technique and Geographic Information System (GIS).

The terrace rice fields and subak as one of the tourism destinations in agriculture tourism have infrastructure assets that need to be maintained. Infrastructure Asset Management (IAM) is defined as the study field, the science and the program to manage the infrastructure life in order to allow well purpose in a sustainable way, efficient and effective. The IAM has several stages such as policy, idea, planning, design, construction, certification, utilization, evaluation, and disposal (Suprayitno \& Soemitro, 2018).

Technological developments make it possible to develop agricultural infrastructure asset management, such as land management, irrigation infrastructure asset, and irrigation water management by using remote sensing-based and integrated with GIS. The objective of this study is to review and analyze strategies on how remote sensing satellite technology and GIS can be used in irrigation water management, so as to have an impact on the sustainability of tourism potential in the Bali Province.

\section{RESEARCH METHODS}

The assessment to obtain the use of integration of remote sensing and GIS in irrigation water management in Bali is carried out by examining various sources of literature on the types of platforms and sensors used in supporting agriculture and irrigation water management. Point to grid analysis was used to examine the monthly average rainfall from IMERG (Integrated Merge Multi-Satellite Retrievals of GPM) and CHIRPS (Climate Hazard Group Infra-Red Precipitation with Station) datasets corresponding to rain gauges data.

\section{DATA COLLECTION}

The daily ground rainfall data for 27 rain gauge stations from 2015-2017 was acquired by Balai Wilayah Sungai Bali-Penida (BWSBP) Ministry of Public Work and Human Settlements of Indonesia. The rainfall satellite product used is daily IMERG version 05 data with $0.1^{\circ}$ spatial resolution and can be downloaded online at https://pmm.nasa.gov/dataaccess/downloads/gpm. The daily CHIRPS version 2 precipitation dataset with spatial $0.05^{\circ}$ also available online at ftp://ftp.chg.ucsb.edu/pub/org/chg/products/CHIRPS-2.0/.

\section{RESEARCH ANALYSIS}

\section{Subak Management System}

The subak system is a traditional irrigation system in Bali that regulates the distribution of water to rice fields in a social, technical, religious, and agricultural relationship (Norken et al., 2015). It consists of irrigation networks, organizational structures, and regulations. Irrigation infrastructure is built because it is needed to carry out the irrigation function in certain 
irrigation areas (Suprayitno \& Soemirto, 2018). Irrigation networks in the subak system generally consist of weirs, canals (primary, secondary, tertiary, and quarterly), and distribution water structure (box structure) that will flow the water to the rice fields. Pictures of weir and distribution water structure can be seen in Figures 1 to 3. Other complementary infrastructures contained in the subak irrigation system are the meeting hall (bale subak) and temple (Pura subak).

The arrangement for the distribution of water rights to rice fields is adjusted to the area of irrigated land using the water distribution unit system (tetek/kecoran). The distribution unit has dimensions of 5-8 cm in width and 1-2 cm in height which are flowed from the primary canal to the rice field with a continuous flow system (Yekti et al., 2017). The water distribution scheduling system is based on cropping patterns, season, a period of water use rights in one year, and time to start the land preparation in the rice planting season (Yekti et al., 2017).

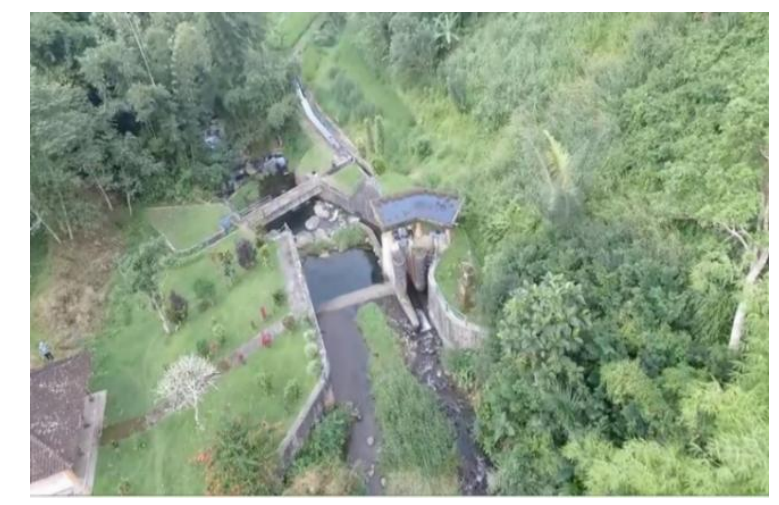

Figure 1. Weir and Primary Canal

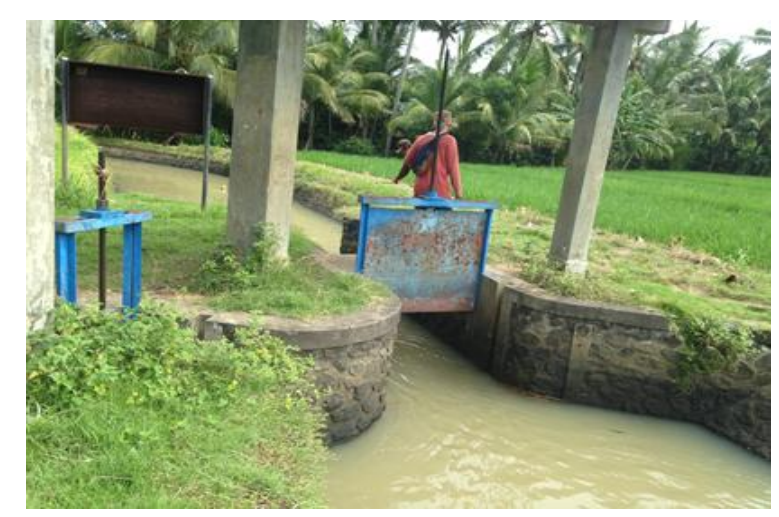

Figure 2. Diversion Structure

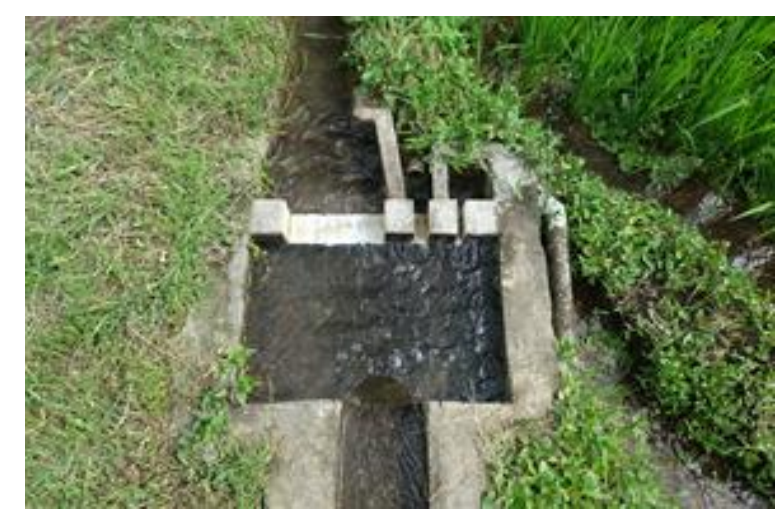

Figure 3. Tertiary Box 
The subak system is also equipped with an organizational structure. Subak, as an autonomous institution, only be responsible directly to its members and coordinates with related agencies, such as the agriculture department, public works department, and income office region. In general, the subak organizational structure consists of the chairman (pekaseh), secretary (penyarikan), treasurer (petengen), announcer (kesinoman/juru arah), regional leader (kelian tempek), and members (krama subak) (Norken et al., 2015). The subak organizational structure can be seen in Figure 4.

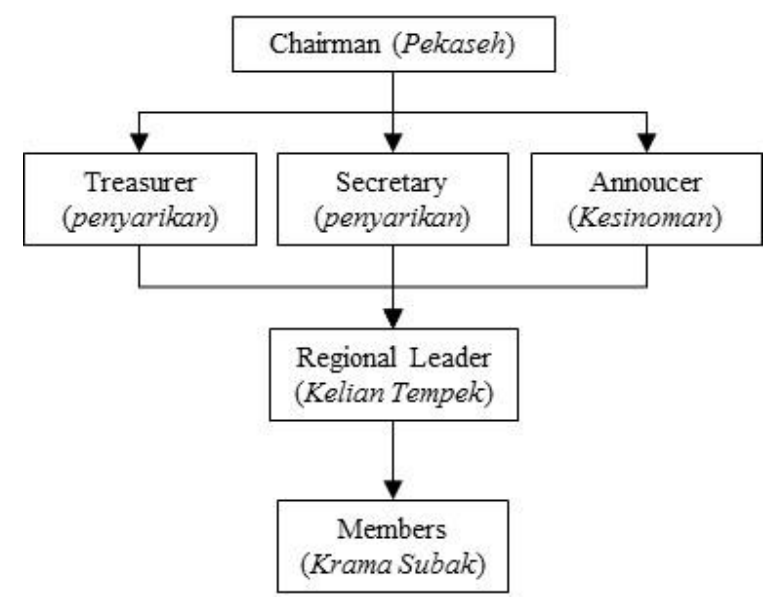

Figure 4. Subak Organizational Structure

The regulations in carrying out irrigation water governance in the subak system are known as awig-awig. This regulation is used to maintain harmonious relations and equality between members. The primary things regulated in awig-awig include membership, organizational structure, rights and obligations of each member, planting patterns, planting schedules, water allocation, water distribution methods, meeting schedules, irrigation network maintenance schedules, finance, types of prohibitions, and sanctions for violations (Sutawan, 2004). Rules are based on aspirations from below that are democratic, fair, wise, and can be adjusted according to conditions.

The government has made efforts to create a sustainable water control system for subaks, including by providing training in operation and maintenance of irrigation networks, facilitating the development of subak institutions into business institutions oriented towards agrotourism/ecotourism, improving irrigation networks with participatory approaches, and acknowledging subak recognition as a legal institution (Yuliana, 2017).

\section{Challenges of Irrigation Water Management}

Subak encounter challenges in managing irrigation water due to economic development, population growth, tourism development in Bali, and global climate change. The challenges faced by subak can be divided into three parts, namely the availability of water, infrastructure, and human resources. The availability of irrigation water currently reduces in particular months, this is due to competition with water users in other fields (Yekti et al., 2017). This has caused a change in the amount of water distribution to each subak member, even though the distribution system has been alternating between regions. Water deficit also causes land conversion to become dry land.

Damage to irrigation infrastructure is also a challenge for subak in managing irrigation water. Damage to canals, waterworks, and dispersion/box structure occurs due to the useful life of the structure and natural disasters (BWSBP, 2017). This damage caused a decrease in the supply of water flowing into the rice fields. Execution of heavy damage is carried out by the public works department, while minor damage is executed by the subaks themselves through membership fees and mutual cooperation. 
Another challenge in the management of irrigation water faced by subak currently is human resources. Subak regeneration is not going well, because the younger generation chose another profession rather than being a farmer (BWSBP, 2017). This eventually induces some agricultural land to be sold, because the next generation nevermore worked as farmers. The relatively old age of farmers causes a limitation of knowledge about modern irrigation operation systems. Public works and agriculture agencies assist subaks in the management of modern irrigation system operations and management of cropping patterns through the counseling.

\section{Irrigation Water Potential}

The river is the key factor for the irrigation system, raw water supply, water storage, hydropower, and drainage system (Maulana, Suprayitno, \& Soemitro, 2019). The source of irrigation water in Bali is generally from the river by building weirs or dams across the river. Based on data from the Statistics of Bali Province, Bali has 246 rivers that flow from upstream and empties into the coast. Total of weirs which is a primary irrigation infrastructure in Bali are128 units. The number of rivers and weirs is a large enough potential to fulfill the water requirements to irrigate rice fields covering an area of $79526 \mathrm{Ha}$. Besides being used as irrigation water, river water is also used to fulfill the requirements of clean water for the community, industrial activities, tourism, and power generation.

River water in Bali is generally sourced from springs and rainfall. The potential for water from rainfall is quite large because Bali is located in a tropical area that has two seasons, namely the wet season (November to April) and the dry season (May to October) This season is affected by monsoons wind that change every six months (Aldrian \& Dwi Susanto, 2003). Based on data from 27 rain stations from the Balai Wilayah Sungai Bali-Penida (BWSBP) from 2015 until 2017, the average monthly and annual rainfall in the province of Bali is around 180 $\mathrm{mm} / \mathrm{month}$ and $2100 \mathrm{~mm} / \mathrm{year}$, where peak rainfall occurs in December to February.

Remote sensing technology can also be used to determine the rainfall potential in Bali Province. Satellite is one of the remote sensing techniques that has the advantage of very wide area coverage. Satellite precipitation product estimates (SPPEs) have been developed starting from 1997 until now. Some examples of SPPEs are Tropical Rainfall Measuring Mission (TRMM), Precipitation Estimation from Remotely Sensed Information Using Artificial Neural Networks (PERSIANN), Climate Prediction Center (CPC) Morphing algorithm (CMORPH), Global Satellite Mapping of Precipitation (GSMaP), and Integrated Merged MultisatellitE Retrievals for GPM (IMERG), Climate Hazards Group Infra Red Precipitation with Station (CHIRPS).

The results of the IMERG and CHIRPS dataset analysis show that the amount and pattern of rainfall each month is almost the same as the rain gauge stations (Figure 5). The average monthly and annual rainfall from IMERG is around $190 \mathrm{~mm} / \mathrm{month}$ and $2300 \mathrm{~mm} / \mathrm{year}$, while CHIRPS is around $185 \mathrm{~mm} / \mathrm{month}$ and $2200 \mathrm{~mm} /$ year. This shows that rainfall data from satellite precipitation datasets can be used as an alternative in analyzing rainfall potential, hydrological modeling, water resources management, flood monitoring, and drought monitoring (Setiawati, Miura, \& Aryastana, 2016; Xu et al., 2017; Ayehu, Tadesse, Gessesse, \& Dinku, 2018). 


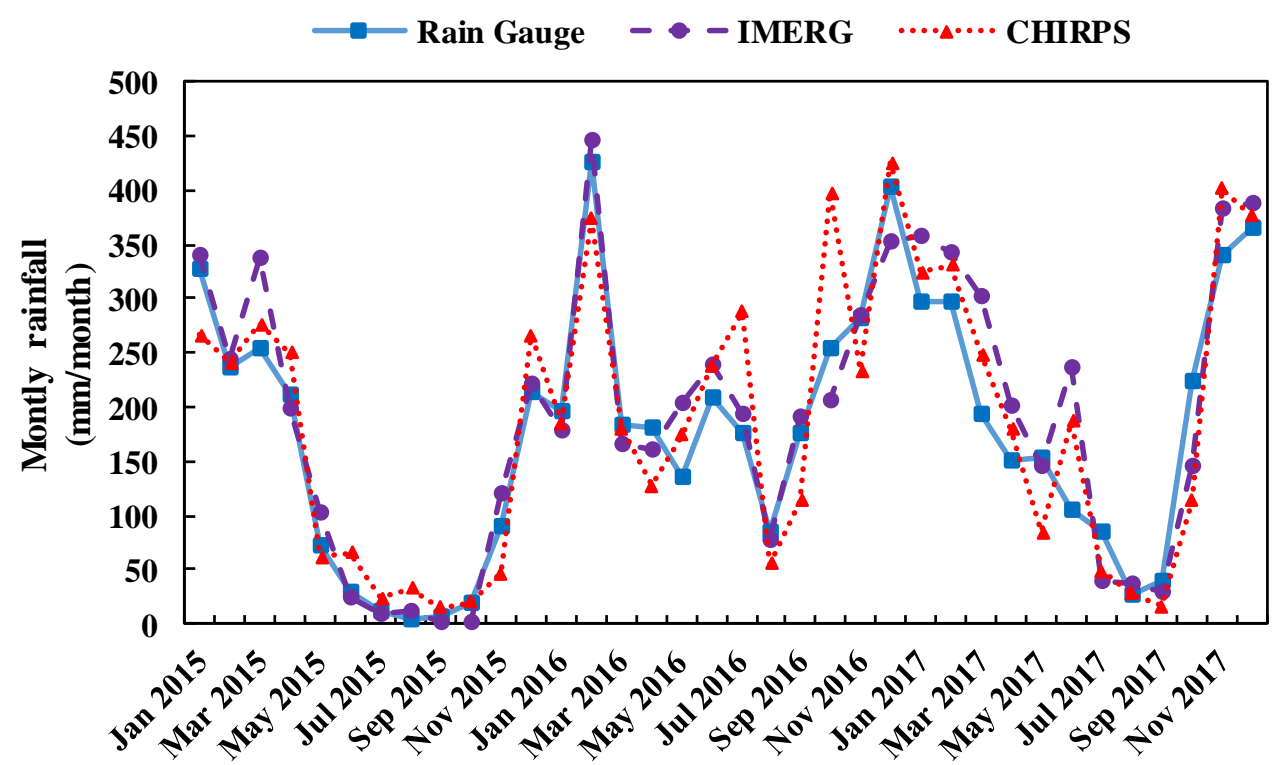

Figure 5. Average Monthly Rainfall in Bali from 2015-2017 based from 27 rain gauges, IMERG, and CHIRPS datasets

\section{Applications of Remote Sensing and GIS}

The distribution of agricultural irrigation water who managed by subak has indeed run well for hundreds of years. The existing challenges required an irrigation water management system that is more effective and efficient following current technological developments so that the sustainability of the subak can be maintained. The irrigation water management based on remote sensing and GIS system is needed to resolve the reduction in the amount of irrigation water due to conflicts of interest with other users.

Remote sensing is a technology in obtaining information about an object without making direct contact with the object. Remote sensing has several advantages compared to field measurements including covering a large area, objective, systematic, can be represented spatially through a GIS, and provide more detailed information related to spatial uniformity (Bastiaanssen, Molden \& Makin, 2000; Bello, Nasidi \& Shanono, 2014).

The remote sensing data acquisition system consisting of the platform and sensor. The platforms used in remote sensing technique can be aircraft, balloons, Unmanned Aerial Vehicle (UAV), drone, and satellites. The usefulness of each platform in agriculture and irrigation water management can be seen in Table 1. The sensor in remote sensing can be divided into passive and active sensors. Satellite uses the passive sensor to acquiring data. The types of sensors that are often used in agriculture and irrigation water management can be seen in Table 2.

Table 1. Remote Sensing Platform for Agriculture and Irrigation Management

\begin{tabular}{cll}
\hline No & Platform & Application \\
\hline 1 & Aircraft/ & a. Monitoring of crop type and yield estimation \\
& UAV/Drone & b. Spray pesticides on plants. \\
2 & Satellites & $\begin{array}{l}\text { a. Identification of land use. } \\
\text { b. Identification of irrigation area and infrastructure. }\end{array}$ \\
& & $\begin{array}{l}\text { c. Identification of the water supply source (river discharge). } \\
\text { d. Analysis of water use, water rights, irrigation scheduling, nursery } \\
\end{array}$ \\
& & monitoring, crop disease detection, evaluate fruit maturity, detection \\
& &
\end{tabular}


Table 2. Satellite Sensor/Band for Agriculture and Irrigation Management

\begin{tabular}{clll}
\hline No & Sensor/ Band & Outcomes variable & Utilization \\
\hline 1 & $\begin{array}{l}\text { Visible and near- } \\
\text { infrared }\end{array}$ & $\begin{array}{l}\text { Evapotranspiration, crop } \\
\text { type, crop yield, land } \\
\text { use, irrigation area } \\
\text { Crop moisture content }\end{array}$ & $\begin{array}{l}\text { Water use, water rights, irrigation } \\
\text { scheduling, and productivity. }\end{array}$ \\
2 Thermal infrared & $\begin{array}{l}\text { Water rights, irrigation scheduling, } \\
\text { yield estimates, nursery monitoring, } \\
\text { crop disease detection, evaluate } \\
\text { fruit maturity, and detection of } \\
\text { bruises on fruit. } \\
\text { Irrigation water potential (river } \\
\text { discharge). }\end{array}$ \\
& $\begin{array}{l}\text { Passive microwave } \\
\text { and thermal infrared }\end{array}$ & Precipitation & \\
\hline
\end{tabular}

GIS is "an organized compilation of database, application, hardware, software, and trained manpower competent of capturing, manipulating, organization, and analyzing the spatial reference database and production of output both in tabular and map form". Currently, remote sensing has been interconnected with other recent geospatial technology such as a global positioning system (GPS) and GIS. The integration of remote sensing and GIS helps in the proper management of water for agriculture and produces more precise analysis results (Kumar, Dubey, \& Ghosh, 2014).

The use of remote sensing technology and GIS is very widely in agriculture and irrigation water management, including:

1. Integration of Landsat image, Digital Elevation Model (DEM), and field data by GIS produce land utilization types of irrigation (Ismail, Abdel Ghaffar, \& Azzam, 2012).

2. Irrigation water management under the semi-arid condition in Andalusia, Southern Spain by using the European Organization for the Exploitation of Meteorological Satellites (EUMETSAT) Satellite Applications Facility for Land Surface Analysis (LSA SAF). Evapotranspiration approach success was used to analyze irrigation scheduling and yield estimation (Cruz-Blanco, Lorite, \& Santos, 2013).

3. Analysis of irrigation scheduling, yield estimates, crop disease detection, evaluate fruit maturity, and detection of bruises on fruit by using thermal imaging (Ishimwe, Abutaleb, \& Ahmed, 2014).

4. Subak zonation classification and land-use change of rice field in Bali by using a numerical classification based on Quickbird, Aster, and Landsat images where the accuracy of image interpretation is around $98.5 \%$. Classification can be divided into three, subak whose land can sustainable, buffer subak, and subak has a possibility to change functions. Conversion paddy fields in Bali from 2002 until 2013 is 1289.53 ha/year (Lanya et al., 2015).

5. Water depth irrigation system by calculating the Coefficient of Uniformity (CU) of water distribution, Normalized Difference Vegetation Index (NDVI), Normalized Difference Water Index (NDWI), and Land Surface Temperature (LST) based on Landsat 8 satellite image eastern Nile delta. The water depth estimation value shows a very high correlation compare with actual water depth value (Farg, Arafat, Abd ElWahed, \& El-Gindy, 2017).

6. Quantifying of water use pattern and evaluating crop performance based on 3396 Landsat images over the Palo Verde Irrigation District along with climatic parameters (atmosphere water demand, air temperature, and precipitation) and agro-hydrologic variables (actual evapotranspiration, land surface temperature, runoff, and NDVI). Big Landsat data was used for planning irrigation water allocation, managing water rights, 
crop production control, quantifying consequences of land cover changes on irrigation area (Senay, Schauer, Friedrichs, Velpuri \& Singh, 2017).

7. Development of Internet of Things (IoT) in agriculture applications. IoT was used for water management, crop management, smart farming, livestock management, and irrigation management. IoT uses sensors to collect data. The type of data collected is temperature, humidity, soil moisture, soil $\mathrm{PH}$, and water level. Transfer data technology used in IoT include Wi-fi, Mobile Technology, Raspberry pi, ZigBee, wireless sensor network, Bluetooth, LoRa, GPRS, RFID, and LAN. IoT can make agriculture processing more efficient and increasing crop production (Madushanki, Halgamuge, Wirasagoda, \& Syed, 2019).

With the character of the irrigation area in Bali which is quite large and relatively irregular landforms (terracing paddy field), mapping analysis of irrigation areas with field measurements will take a long time and require enormous resources. The combination of satellite imagery technology and GIS can be used as an alternative in irrigation water management in Bali.

\section{CONCLUSION}

Irrigation is an important component in agricultural production and supporting tourism in the Province of Bali. The challenges faced in irrigation water management are the existence of deficit water due to conflicts with other users, damage to irrigation infrastructure, and limited human resources. Remote sensing technology is useful in determining the land use, irrigation area, irrigation infrastructures, water supply source, water use, crop type, water rights, irrigation scheduling, yield estimates, nursery monitoring, crop disease detection, evaluate fruit maturity and detection of bruises on fruit. With remote sensing technology and GIS, it is hoped that irrigation infrastructure assets and water management in Bali will become more effective and efficient so that the preservation of paddy fields is maintained in supporting the sustainability of tourism potential. Remote sensing technology and GIS may not provide all the data needed for irrigation infrastructure asset and water management, but additional data from the field is still needed to complete and validate the results of the remote sensing analysis.

ACKNOWLEDGMENT. Authors would like to thank Balai Wilayah Sungai Bali-Penida (BWSBP) Ministry of Public Work and Human Settlements of Indonesia for supporting gauge station rainfall data over Bali Island. The authors also would like to thanks IMERG and CHIRPS website (https://pmm.nasa.gov/dataaccess/downloads/gpm and ftp://ftp.chg.ucsb.edu/pub/org/chg/products/CHIRPS-2.0/) for providing precipitation datasets. Geophysical Radiation and Atmospheric Composition Exploration Laboratory (GRACE Lab) of the Center for Space and Remote Sensing Research (CSRSR) National Central University also gratefully acknowledgment for the facilities provided. This paper has been selected from $2^{\text {nd }}$ WUICACE 2019, organized by the Faculty of Engineering, Warmadewa University.

\section{REFERENCES}

Aldrian, E., \& Dwi Susanto, R. (2003). "Identification of three dominant rainfall regions within Indonesia and their relationship to sea surface temperature". International Journal of Climatology, 23(12), 1435-1452. https://doi.org/10.1002/joc.950

Ayehu, G. T., Tadesse, T., Gessesse, B., \& Dinku, T. (2018). "Validation of new satellite rainfall products over the Upper Blue Nile Basin, Ethiopia". Atmospheric Measurement Techniques, 11(4), 1921-1936. https://doi.org/10.5194/amt-11-1921-2018

Bastiaanssen, W. G. M., Molden, D. J., \& Makin, I. W. (2000). "Remote sensing for irrigated agriculture: Examples from research and possible applications". Agricultural Water Management, 46(2), 137-155. https://doi.org/10.1016/S0378-3774(00)00080-9

Bello, M. M., Nasidi, N. M., \& Shanono, N. J. (2014). "Remote Sensing as a Tool for Irrigation Water Management". The $1^{\text {st }}$ International Conference on Drylands, 56-60. Kano: Centre for Dryland Agriculture. 
BPS. (2018). Bali Province in Figures 2018. Denpasar: BPS - Statistics of Bali Province.

Budiasa, I. W., \& Ambarawati, I. G. A. A. (2014). "Community-Based Agro-tourism as an Innovative Integrated Farming System Development Model Towards Sustainable Agriculture and Tourism in Bali". Journal of the International Society for Southeast Asian Agricultural Sciences, 20(1), 29-40.

BWSBP. (2017). Desain Peningkatan / Rehabilitasi Infrastruktur Jaringan Irigasi DAS Tk. Unda dan DAS Tk. Petanu. Balai Wilayah Sungai Bali Penida. Denpasar.

Cruz-Blanco, M., Lorite, I. J., \& Santos, C. (2013). "An Innovative Remote Sensing based Reference Evapotranspiration Method to Support Irrigation Water Management under Semi-arid Conditions". Agricultural Water Management, 131, 135-145. https://doi.org/10.1016/j.agwat.2013.09.017

Farg, E., Arafat, S., Abd El-Wahed, M. S., \& El-Gindy, A. (2017). "Evaluation of water distribution under pivot irrigation systems using remote sensing imagery in eastern Nile delta". Egyptian Journal of Remote Sensing and Space Science, 20, S13-S19. https://doi.org/10.1016/j.ejrs.2016.12.001

Fowler, P. J. (2003). Word Heritage Papers 6: World Heritage Cultural Landscapes 19922002. Paris.

Ishimwe, R., Abutaleb, K., \& Ahmed, F. (2014). "Applications of Thermal Imaging in Agriculture-A Review". Advances in Remote Sensing, 03(03), 128-140. https://doi.org/10.4236/ars.2014.33011

Ismail, M., Abdel Ghaffar, M. K., \& Azzam, M. A. (2012). "GIS application to identify the potential for certain irrigated agriculture uses on some soils in Western Desert, Egypt". Egyptian Journal of Remote Sensing and Space Science, 15(1), 39-51. https://doi.org/10.1016/j.ejrs.2012.03.001

Kumar, A., Dubey, O. P., \& Ghosh, S. K. (2014). "GIS-Based on Irrigation Water Management. International Journal of Research in Engineering and Technology, 3(14), 62-65. Retrieved from http://www.ijret.org

Lanya, I., Subadiyasa, N. N., Sardiana, K., \& Adi, G. P. R. (2015). "Numerical Classification, Subak Zoning and Land Transfer Function Rice Field in the Province of Bali Based on Remote Sensing and GIS". Procedia Environmental Sciences, 24, 47-55. https://doi.org/10.1016/j.proenv.2015.03.008

Madushanki, A. A. R., Halgamuge, M. N., Wirasagoda, W. A. H. S., \& Syed, A. (2019). "Adoption of the Internet of Things (IoT) in agriculture and smart farming towards urban greening: A review". International Journal of Advanced Computer Science and Applications, 10(4), 11-28.

Maulana, M. A., Suprayitno, H., \& Soemitro, R. A. A. (2019). "Preliminary Recognition of River Infrastructure". Journal of Infrastructure \& Facility Asset Management, 1(1), 1-9.

Mitchell, B. (1994). "Sustainable Development at the Village Level in Bali, Indonesia". Human Ecology, 22(2), 189-211. https://doi.org/10.1007/BF02169039

Norken, I. N., Suputra, I. K., \& Arsana, I. G. N. K. (2015). "Water Resources Management of Subak Irrigation System in Bali”. Applied Mechanics and Materials, 776, 139-144. https://doi.org/10.4028/www.scientific.net/amm.776.139

Roth, D. (2011). "The Subak in Diaspora: Balinese Farmers and the Subak in South Sulawesi". Human Ecology, 39(1), 55-68. https://doi.org/10.1007/s10745-010-9374-7

Senay, G. B., Schauer, M., Friedrichs, M., Velpuri, N. M. \& Singh, R. K. (2017). "Satellitebased water use dynamics using historical Landsat data (1984-2014) in the southwestern United States". Remote Sensing of Environment, 202, 98-112. https://doi.org/10.1016/j.rse.2017.05.005

Setiawati, M. D., Miura, F., \& Aryastana, P. (2016). "Validation of Hourly GSMaP and Ground base Estimates of Precipitation for Flood Monitoring in Kumamoto, Japan". In P. K. 
Srivastava, P. C. Pandey, P. Kumar, A. S. Raghubanshi, \& D. Han (Eds.), Geospatial Technology for Water Resource Applications (pp. 130-143). https://doi.org/10.1201/9781315370989

Sørdalen, T. K. (2011). A Traditional Irrigation System in Bali ; a Study of its Transferability to Flores. The University of Agder.

Suprayitno, H., \& Soemitro, R. A. A. (2018). "Preliminary Reflexion on Basic Principle of Infrastructure Asset Management". Journal of Infrastructure \& Facility Asset Management, 2(1), 1-9.

Sutawan, N. (2004). "Tri Hita Karana and Subak In Search for Alternative Concept of Sustainable Irrigated Rice Culture". INWEPF, 1-11.

Xu, R., Tian, F., Yang, L., Hu, H., Lu, H., \& Hou, A. (2017). "Ground validation of GPM IMERG and TRMM 3B42V7 rainfall products over southern Tibetan plateau based on a high-density rain gauge network". Journal of Geophysical Research, 122(2), 910-924. https://doi.org/10.1002/2016JD025418

Yekti, M. I., Schultz, B., Norken, I. N., \& Hayde, L. (2017). "Discharge Analysis for a System Approach to River Basin Development with Subak Irrigation Schemes as a Culture Heritage in Bali". Agricultural Engineering International: CIGR Journal, 19(1), 33-44.

Yuliana, E. D. (2015). "Renewable Irrigation System in the Land Rice Field of Subak in Bali". Academic Research International, 6(2), 38-43.

Yuliana, E. D. (2017). "SUBAK : Traditional Irrigation Organization A Cultural Representation of Agriculture in Bali". International Journal of Contemporary Research and Review, 08(06), 20179-20185. https://doi.org/10.15520/ijcrr/2017/8/05/180 